\title{
Transnational 'Italian' Stardom: Lara Saint Paul and the Performativity of Race
}

Cecilia Brioni and Simone Brioni

School of Histories, Languages and Cultures, University of Hull, UK ; Department of

English, Stony Brook University, Stony Brook, NY, USA

This article aims to contribute to the debate about critical race studies in the Italian context - and especially in the 1960s and the 1970s - by focusing on the construction and negotiation of race in the career of the prominent Italian meticcio singer, television host and producer Silvana Areggasc Savorelli, also known as Tanya from 1960 to 1966 and Lara Saint Paul from 1967 onwards. Through an examination of Savorelli's career as a singer, television host and Italian diva, this article shows how the meanings of Savorelli's meticcio body have been constantly adapting to the shifting perceptions of blackness in Italy and other Western societies. Lara Saint Paul's media representations illustrate a change in the social construction of Italianness in terms of race from the early 1960s to the early 2000s.

Keywords: cultural translation; critical race studies; transnational stardom; postcolonial theory; Lara Saint Paul; popular music

"Black is beautiful" is never superficial and always political. ${ }^{1}$ Becoming Black and being Black are framed by hegemonic Blackness and

Whiteness. ${ }^{2}$

Recent studies have initiated the critical reflection about the representation of blackness in Italian Cinema, ${ }^{3}$ the perception of blackness, whiteness and meticciato in

\footnotetext{
${ }^{1} \mathrm{~J}$. Hobson, Venus in the Dark: Blackness and Beauty in Popular Culture (New York; London: Routledge, 2005), p. 148.

${ }^{2}$ S. A. Tate, Black Beauty: Aesthetics, Stylization, Politics (New York; London: Routledge, 2016), p. 53.

${ }^{3}$ L. De Franceschi, ed., L'Africa in Italia. Per una controstoria postcoloniale del cinema italiano (Rome: Aracne, 2013); S. Greene, Equivocal Subjects: Between Italy and Africa -
} 
contemporary Italy, ${ }^{4}$ and the legacy of the racialization of colonialism in the Italian imagination of race. ${ }^{5}$ Some of the scholars who contributed to this lively debate have been interviewed in Fred Kudjo Kuwornu’s Blaxspoitalian. 100 Anni di Afrostorie nel cinema italiano, ${ }^{6}$ a documentary that shows how black presences are unvoiced, misseen, objectified and fetishised in Italian cinema. Moreover, Blaxspoitalian advocates for the inclusion and participation of more African Italian actors and directors, in order to represent the multi-ethnic reality of Italian society.

In looking at the historical construct of race in Italy, it should be noted that the status of Italians as 'white' is a very recent cultural construction, given that throughout history this group was often not seen as such by others - for instance in the United States at the beginning of twentieth century $-^{7}$ and a significant difference has been perceived between Italian Northerners and Southerners by Italians themselves. ${ }^{8}$ According to Gaia Giuliani and Cristina Lombardi-Diop, the legacy of colonialism is key in the contemporary construction of race in Italy, as this enterprise was crucial in unifying the nation and constructing the whiteness of a group that was defined in opposition to the darker African other. After the fall of the Fascist regime:

Constructions of Racial and National Identity in the Italian Cinema (London; New York: Bloomsbury Academic, 2014).

${ }^{4}$ G. Giuliani, ed., Il colore della nazione (Florence; Milan: Le Monnier - Mondadori Education, 2015); and G. Giuliani and C. Lombardi-Diop, Bianco e nero. Storia dell'identità razziale degli italiani (Florence; Milan: Le Monnier - Mondadori Education, 2013).

${ }^{5}$ S. Ponzanesi, Paradoxes of Postcolonial Culture: Contemporary Women Writers of the Indian and Afro-Italian Diaspora (Albany: SUNY Press, 2004); J. Andall and D. Duncan, eds, Italian Colonialism: Legacy and Memory (Oxford: Lang, 2005); J. Andall and D. Duncan, eds, National Belongings: Hybridity in Italian Colonial and Postcolonial Cultures (Oxford: Lang, 2010); and C. Lombardi-Diop and C. Romeo, eds, Postcolonial Italy: Challenging National Homogeneity (Basingstoke:Palgrave Macmillan, 2012).

${ }^{6}$ Blaxspoitalian. 100 Anni di Afrostorie nel cinema italiano, dir. by Fred Kudjo Kuwornu (Blue Rose Film, 2016).

${ }^{7} \mathrm{~J}$. Guglielmo and S. Salerno, Are Italians White?: How Race is Made in America (New York; London: Routledge, 2003).

${ }^{8}$ See N. J. Moe, The View from Vesuvius: Italian Culture and the Southern Question (Oakland, CA: University of California Press, 2002). 
Si affaccia in Italia una bianchezza 'senza razze' che nega di essere razzista e che al contempo naturalizza l'Altro, la sua differenza culturale (e del colore) in senso inferiorizzante, e sé stesso, le proprie caratteristiche storiche e culturali, rinvigorendo l'idea di un'ovvia ('naturale') bianchezza tutta italiana. ${ }^{9}$

The significance of studies that have outlined the presence of racism, white privilege, and colour blindness in Italian culture is invaluable, given that - as Valeria Deplano has argued:

Dopo il crollo del regime fascista il termine 'razzismo' scomparve dal discorso pubblico e dalla legislazione della neonata Repubblica italiana, mentre alla parola 'razza' (o meglio alla formula 'senza distinzione di razza') fu esplicitamente affidato il rifiuto delle discriminazioni basate sull'appartenenza etnica o culturale da parte dello stato italiano 'rigenerato'. ${ }^{10}$

Discourses about a supposed absence of racism against people of African origins in Italy have frequently circulated in popular media discourse, and concerns about racism primarily focused on discrimination of Italian Southerners. For example, in a 1967 reader poll asking Italian young women whether they would 'sposare un negro [sic]', a journalist of the teen magazine Ciao Big claims that

L’Italia non è un paese razzista. Così sostengono quasi tutti gli italiani. Infatti, il razzismo esiste quando esiste un problema razziale. Da noi, invece, non si è mai posto il problema della coesistenza di razze diverse [...]. Abbiamo visto concretamente il razzismo italiano in azione quando ha preso avvio l'immigrazione dal meridione. Quindi, è vero che gli italiani non hanno una tradizione lugubremente razzista, che non sono razzisti fino a quando non hanno bisogno di esserlo. ${ }^{11}$

\footnotetext{
${ }^{9}$ G. Giuliani and C. Lombardi-Diop, Bianco e Nero, pp. 12-13.

${ }^{10}$ V. Deplano, 'Senza distinzione di razza? R azzism o in contro uce ne I d iscorso pubb lico italiano tra anni Cinquanta e anni Settanta,' From the European South, 1 (2016), 95-102 (p. 96). ${ }^{11}$ L. De Carlini, 'L'inchiesta della settimana. E tu, sposeresti un negro?', Ciao Big, 15 December 1967, 98-100 (p. 98).
} 
The article assumes that Italians did not have the opportunity to think about race in the 1960s, because there were no blacks in their country. This opinion was also shared by prominent intellectuals such as Pier Paolo Pasolini. ${ }^{12}$

In the context of the alleged absence of non-white people in Italian society in the 1960s, an examination of Italian popular media products such as TV programmes and magazines reveals that meticcio Italians were indeed present in popular culture, and that the social perception of blackness has shifted throughout the last sixty years of Italian history. This article focuses on a specific case study, namely the construction and negotiation of race in the career of the prominent Italian meticcio singer, television host and producer Silvana Areggasc Savorelli, also known as Tanya from 1960 to 1966 and Lara Saint Paul from 1967 onwards. Savorelli was born in Asmara in 1946 and moved to Italy when she was seven years old. She was the daughter of an Italian father and an Eritrean mother, and she first became popular in Italy as a host of successful television programmes such as Quelli della Domenica and La domenica è un'altra cosa, ${ }^{13}$ and thanks to her appearances in Canzonissima ${ }^{14}$ and in several editions of the Sanremo Music Festival, ${ }^{15}$ the most important annual popular music event in Italy since 1951. Drawing on Richard Dyer's assumption that 'the star phenomenon reproduces the overriding ideology of the person in contemporary society' ${ }^{16}$ and Nicole Fleetwood's idea that 'the discourse of blackness is predicated on a knowable, visible, and

\footnotetext{
${ }^{12}$ P. P. Pasolini, Pasolini su Pasolini: conversazioni con Jon Halliday (Parma: Guanda, 1992), p. 66.

${ }^{13}$ Quelli della Domenica (RAI, 1968; RAI Teche Archives); La domenica è un'altra cosa (RAI, 1969).

${ }^{14}$ Canzonissima (RAI, 1970-71; RAI Teche Archives).

${ }^{15}$ XII Festival della Canzone Italiana - Sanremo (RAI, 1962; RAI Teche Archives); XVIII Festival della Canzone Italiana - Sanremo (RAI, 1968; RAI Teche Archives); XXII Festival della Canzone Italiana - Sanremo (RAI, 1972; RAI Teche Archives); and XXIII Festival della Canzone Italiana - Sanremo (RAI, 1973; RAI Teche Archives).

${ }^{16}$ R. Dyer, Heavenly Bodies: Film, Stars and Society, 2nd edn (London; New York: Routledge, 2004), p. 12.
} 
performing subject', ${ }^{17}$ this article explores what social and cultural values were mapped onto Lara Saint Paul's meticcio body, from the early 1960s to the early 2000s. The article suggests that the construction of stars in popular culture is an ideological process, which functions to reiterate stereotypes, or to subvert prevalent representations of ethnicity, class, gender, and race.

The sources analysed include cultural products such as TV programmes, album covers, and magazines - including Ciao Amici, Big, Playman, and TV Sorrisi e Canzoni - in order to trace chronologically how Savorelli's appearance and musical repertoire changed over time and the multiple sources of inspiration in the construction of her national, racial and ethnic identity. It should be noted that these media products addressed different sections of the Italian audience. While album covers were intended to appeal to youth and music aficionados, television programmes and magazines like Sorrisi e Canzoni TV were aimed at a wider audience of families and adults. This article shows that media representations of Savorelli changed according to the different desired audience of each media product.

The article identifies four phases of Savorelli's career - Tanya as an exotic singer (1962-1967), Lara as an Italian television star (1968-1973), Lara as inspired by African American models of beauty and fashion (1968-1979), and Lara as a white international star (1981-2018) -, by underlining the most prominent traits in Savorelli's appearance and performing style. However, these periods are interdependent and connected, since defining features of a period or a style are sometimes present in others. Savorelli's different performances of her blackness and whiteness show that 'beauty ideals hold within them both performativity and hybridity as they are produced through

\footnotetext{
${ }^{17}$ N. Fleetwood, Troubling Vision: Performance Visuality and Blackness (Chicago: University of Chicago Press, 2011), p. 6.
} 
discourse, brought into being by subjects and are subject to contestation and restless movement'. ${ }^{18}$

\section{Colonial Nostalgia and Exoticism: Tanya (1960-1967)}

According to a 2014 official document of the Italian government which granted this artist a life annuity, Silvana Areggasc Savorelli's music career began in 1960 under the stage name of Tanya and she was soon referred to as 'la perla nera della canzone italiana'. ${ }^{19}$ The popular media construction of this artist in the early 1960s was characterised by an explicit reference to colonialism, exoticism and the dark colour of her skin. In a 1962 article describing the singer, Tanya was defined as 'la faccetta nera della canzone'. ${ }^{20}$ These nicknames show that Savorelli's blackness - and references to an objectified and sexualised image of colonised African women which were present in Italy especially from the beginning of the colonial experience to the mid-1930s - were the prominent defining features in the characterization of Tanya's star persona. ${ }^{21}$

Tanya's debut album, Miracolo/Tu Puoi, was released in 1961, and in the following year she participated in the Sanremo festival singing 'I colori della felicità', a title that perhaps underlines the fact that a 'white' and a 'colored' singer - Wilma De Angelis and Tanya - performed the same song. ${ }^{22}$ The emphasis on Tanya's black skin can also be found in Sorrisi e Canzoni $T V$ - the magazine that officially covered the

\footnotetext{
${ }^{18}$ S. A. Tate, Black Beauty, p. 150.

${ }^{19}$ Presidenza del Consiglio dei Ministri, 'Assegno Straordinario Vitalizio a favore di cittadini illustri - Scheda personale di Areggasc Savorelli Silvana (in arte Lara Saint Paul)' $<$ http://presidenza.governo.it/GovernoInforma/documenti/bacchielli/Silvana_Areggasc_Savorell i.pdf > [Accessed 16 May 2017].

${ }^{20}$ R. D’Intino et al., 'Il festival confidenziale', Sorrisi e Canzoni TV, 18 February 1962, 10-14 (p. 14).

${ }^{21}$ G. Tomasello, L'Africa tra mito e realtà: storia della letteratura coloniale italiana (Palermo: Sellerio, 2004), pp. 211-13.

${ }^{22}$ Two artists sang the same song at Sanremo festivals in the 1960s, because the competition gave an award for the best song rather than the singers' performance.
} 
festival - which defines the singer as 'una cantante di colore convocata all'ultimo momento' ${ }^{23}$ and 'la piccola Tanya dalla pelle scura'. ${ }^{24}$ A journalist also asks Tanya whether she 'punt[i] molto sul colore della pelle' and she replies: 'Ho cercato di farla diventar bianca con un nuovo prodotto, ma non ci son riuscita. Vatti a fidare della pubblicità'. ${ }^{25}$ This sentence acknowledges Tanya's embarrassment with her skin colour and her desire to conform to white beauty standards. Just like an image of the singer published in Sorrisi e Canzoni TV, the cover of the single Miracolo/Tu Puoi highlights Tanya's blackness through the saturated colours of the photograph. She is cast as a pubescent and exotic beauty: she has long frizzy hair that flows over her left shoulder, and she wears a red dress that matches her red lipstick.

However, Savorelli's career as Tanya was not particularly successful: her song did not make it to the second round at the Sanremo festival, and popular magazines at the time did not feature stories about her public and private life. A 1969 article tracing Savorelli's career published in the teen magazine Ciao Duemilauno states that her appearance as Tanya was not appealing for the early 1960s audience:

Visto che la ragazza è nata ad Asmara ed ha una compatta e vellutata pelle nera, il primo nome con il quale si pensa di lanciarla, a un Sanremo di otto anni fa, è: Tanya. Epidermide color cioccolato e un nome che odorava di Africa a miglia di distanza dovevano essere il passaporto per il successo. Ma non fu così. ${ }^{26}$

The lack of success of Tanya's star persona might be explained by the fact that, although a sense of colonial nostalgia was permeating images of the black other in

\footnotetext{
${ }^{23}$ R. D’Intino, 'Le strane reclute del Festival', Sorrisi e Canzoni TV, 4 February 1962, 14-17 (p. 17).

${ }^{24}$ G. Ruffo, ‘Colbacchi e sombreros per le vie di Sanremo’, Sorrisi e Canzoni TV, 18 February 1962, 15-17 (p. 16).

${ }^{25}$ P. Novelli, 'Le domande cattive ai personaggi del Festival', Sorrisi e Canzoni TV, 18 February 1962, p. 20.

${ }^{26}$ E. Lamberti, 'Il tema di Lara’, Ciao Duemilauno, 3 September 1969, 34-37 (p. 35).
} 
Italian society, new cultural references - coming in particular from the United States were starting to influence the construction of blackness in Italian popular culture.

In 1964, Tanya's star image began to be connected with an exotic Caribbean and Southern American context, rather than with African imagery. For instance, she performed the songs 'Calypso twist' and 'Mexico twist' in the film Due mattacchioni al Moulin Rouge. ${ }^{27}$ In these performances - which are unrelated to the plot of the movie Tanya has her hair worn tied back from her face in a beehive, which was a popular hairstyle during the early 1960s. The performance is set in a space that looks like a cave, and the dancers accompanying the singer wear outfits embellished with ruffles and polka dots, which recall Brazilian carnival costumes. The 1965 song 'L'hawaiana' also presents an exotic reference to the leisure and colonial imagery of 1950s-1960s United States, ${ }^{28}$ thus demonstrating the increasing influence of American popular culture on Italian cultural products and media representations.

The representation of Tanya's star persona shows a tension between the reference to a shared colonial imagery which was still alive in the memory of many Italians, and the attempt to associate Tanya's non-white skin to a non-African environment in order to forget Italian colonialism, given that in 1960 Italy lost the trusteeship administration of Somalia. On the one hand, the singer's star persona was influenced by the colonial image of the bella abissina, as the recurring references to her skin coulour and the language used to introduce her in popular magazines demonstrate. On the other hand, references to 'other' colonial imageries - including those related to Hawaii and Mexico which originated in the United States - in Tanya's cinematic presentation suggest an attempt to erase the traumatic collective memory of the Italian

\footnotetext{
${ }^{27}$ Due Mattacchioni al Moulin Rouge, dir. by Giuseppe Vari(Telefilm Industria, 1964).

${ }^{28}$ D. M. Caporoso Konzett, Hollywood's Hawaii: Race, Nation and War (New Brunswick: Rutgers University Press: 2017), pp. 135-94.
} 
colonial enterprise and to resignify the singer's blackness, which was still the defining trait of her star persona.

The cover of the album L'hawaiana presents Savorelli's face in the foreground, and emphasises a beauty spot on her right cheek, which was the trademark of the famous Italian singer and television host Mina (born Anna Maria Mazzini). This trait anticipates the singer's metamorphosis into Lara Saint Paul, who also had a beauty spot on the left cheek. The reference to an Italian star is nonetheless an exception in Tanya's career, as her presentation draws on a geographically vague exoticism ranging from Africa to South America, that in the first part of her career bears memory of the colonial imagery of the faccetta nera.

\section{Almost Mina, but not Quite: Lara Saint Paul as an Italian Diva (1967-1971)}

From 1967, Savorelli gained popularity under a new stage name - Lara Saint Paul, often shortened to Lara - and her appearance in magazine pictures and television programmes began to conform to Western white standards of beauty. While Tanya had curly, long and frizzy hair, Lara’s star persona was characterised by straight hair and a lighter skin tone. Moreover, her new French-sounding stage name gave the singer a more international allure. Arguably, Lara’s new manager, Pier Quinto Cariaggi - who also became her husband one year later - played a role in her growing success and in the construction of a whole new star persona.

In 1968 Lara became a significant presence in Italian television as she was the main female co-host of the successful television programme Quelli della domenica, which lasted 24 episodes. $^{29}$ Not only did her position in the show recall Mina's

\footnotetext{
${ }^{29}$ The RAI (the Italian national television and radio service) multimedia catalogue does not specify when each episode was aired.
} 
prominent role in programmes such as Studio Uno, ${ }^{30}$ but in her performances she also increasingly appropriated several bodily features of Mina, such as the use of hand gestures as a vehicle to express emotions to the audience. ${ }^{31}$ The two singers also shared a similar style, which in their television performances was made up of long evening gowns and heavy make-up. Lara’s similarities to Mina might be seen as a strategy to align to the glamour and beauty standards of Italian divas, and therefore to emphasise her Italianness. It should also be noted that Lara's first album features a song in Neapolitan dialect, 'Te Faje Desiderà', which she sang at the 15th Festival of Neapolitan Music. This choice should not seem unusual, given that Mina also released an album in Neapolitan in 1966: Mina canta Napoli. Like Mina - who was born in Lombardy - Savorelli had no Neapolitan background, as she spent her childhood in the region of Romagna: Lara's performance of 'Te Faje Desiderà' therefore functions to connect her star persona with traditional Italian popular music, such as Neapolitan songs, and to appeal audiences in Southern Italy.

Three elements characterised Lara's performances in Quelli della Domenica and allow us to understand her appeal to Italian audiences: her friendliness and wit, her impressive singing skills, and her versatility. At the beginning of each episode, Lara supported the comic duo Ric and Gian (Riccardo Miniggio and Gian Fabio Bosco) in a comic sketch. For instance, in an episode, Lara, Ric and Gian joke with each other through a song: Lara says that actors and comedians Franco Franchi and Ciccio Ingrassia are more elegant than Ric and Gian, Ric and Gian tell Lara that all of her songs are similar, and they finally unite and jokingly say that Paolo Villaggio - another comedian and presenter of Quelli della Domenica - is a mean person. Lara's physical

\footnotetext{
${ }^{30}$ Studio Uno (RAI, 1961-1965; RAI Teche Archives).

${ }^{31} \mathrm{R}$. Haworth, 'Making a Star on the Small Screen: The case of Mina and RAI', Journal of Italian Cinema \& Media Studies, 3.1-2 (2015), 27-41 (p. 32).
} 
appearance adds to her appeal, but her ability to sing songs with a very personal style and her role as a comedy partner are key to the construction of her star persona. Lara's male colleagues constantly show appreciation for her remarkable singing skills, and she does not occupy a subordinate role with respect to them. Moreover, in Quelli della Domenica Lara performs songs in several Italian dialects - in the last episode, for instance, she sings 'Crapa Pelada' in Milanese dialect and Roman folk songs - therefore conveying a star image that is increasingly defined as Italian. In the twelve episodes of the programme that are available in the RAI multimedia catalogue, ${ }^{32}$ there is no reference to Savorelli's skin colour and origins. The only connection between Lara and exoticism is the performance of 'Che mele', a song that Lidia Martorana debuted in 1949. This song has a clear sexual and exotic allusion about the juicy apples that come from Caracas, and Lara sings it while carrying a basket full of tropical fruit. However, this is just one of the many costumes that Lara wears in the show. In her sketches with Ric and Gian, she dresses up in costumes which identify with different national and ethnic groups at different times: French, Scottish, Romani, Brazilian, and Spanish. At the end of each episode of Quelli della Domenica, Lara also sings the programme's theme song within different sceneries, which include the Andes, Greece, Russia, the Circus and a foxhunt. To sing songs taken from different world cultures was indeed a standard in Italian entertainment programmes of the 1960s. For example, in an episode of Studio Uno 1961 Mina sings a song in Japanese and dresses like a Geisha on stage. In Quelli della Domenica, then, Lara is not identified as an exotic presence, but as a versatile performer who might sing an exotic song like 'Che Mele' as part of her role as an Italian television host. Lara's performances can shed a light on the attempt to

\footnotetext{
${ }^{32}$ The RAI multimedia catalogue, which includes these videos, is not freely available online. It can be accessed from RAI libraries and regional offices, and from selected libraries in Rome and Milan.
} 
'domesticate' and increasingly 'Italianise' this artist, therefore making her more acceptable to the general audience.

In 1968, Lara performed the song 'Mi va di cantare' with the African American singer and musician Louis Armstrong at the Sanremo festival. In the 1968 edition, the structure of the festival was slightly modified, and both an Italian and an international artist - rather than two Italian singers - sang the same song in the show. It can be argued that the coupling of Lara and Armstrong clearly posited the former singer as the Italian artist, no matter the colour of her skin, or at least showed a difference between the glamorous, graceful and whiter African Italian and the rough and darker African American. This collaboration also emphasised Lara's whiteness, given that Armstrong's skin tone was much darker. For example, the cover of the 1969 album Che pazza la vita presents a picture of Lara in colour on the left and one of Armstrong in black and white and much smaller than her on the right. Armstrong's arms are lifted and he is looking at Lara with an expression of enthusiastic marvel. The strong colour contrast between these two pictures emphasises Lara's lighter skin. It can also be argued that Lara's and Armstrong's different singing styles in their performance at the 1968 Sanremo festival tended to emphasise Lara's Italianness. While Lara's style was influenced by the Italian canzone and by artists like Mina, Armstrong 'came out of the minstrel tradition. The stereotypical darky, with his shuffling feet, his rolling eyes, his dice and his tambourine, was at the heart of black entertainment'. ${ }^{33}$

Unlike Tanya's descriptions in 1962, Sorrisi e Canzoni TV in 1968 identifies Lara as white and Italian, ${ }^{34}$ as her name does not appear in an article named 'La faccia

${ }^{33}$ J. L. Collier, Louis Armstrong: An American Genius (Oxford: Oxford University Press, 1985), p. 304.

${ }^{34}$ A. Buratti, 'Pronti all'attacco dei Big Stranieri', Sorrisi e Canzoni TV, 04 February 1968, pp. 24-27. 
nera del festival', ${ }^{35}$ in which all the black participants to the festival - including Shirley Bassey, Eartha Kitt, Wilson Pickett, and Dionne Warwick - were presented. In another article on the festival, Lara and singer Little Tony (Antonio Ciacci) are described as 'stranieri "finti”' because they were born respectively in Asmara and San Marino, ${ }^{36}$ thus acknowledging their liminal role as 'foreigners', yet ultimately emphasising their Italianness.

Although Lara was not white like other Italian female stars because of the colour of her skin, she was characterised by values - such as a strong sense of family and sexual respectability - that defined her femininity as 'Italian', unlike other African American artists who were present in Italian television. In 1968, Lara wrote an article for Sorrisi e Canzoni TV where she describes her trip to the US to visit her friend Armstrong. In this article, the singer recounts how an American photographer, given her dark skin, asked whether she wanted to pose for a naked photo shoot. Lara gets upset and replies that she is Italian, therefore she would not accept to appear in such kind of pictures. ${ }^{37}$ Lara's Italianness here grants her respectability, against the stereotype of the sexually available Black Venus.

In this sense, Lara was differently constructed from coeval black personalities in Italian television, such as the dancer and television host Lola Falana, often named 'la venere negra'. ${ }^{38}$ Falana was an African American dancer who became popular in Italy thanks to television programmes such as Sabato Sera. ${ }^{39}$ In Italian popular media products, Falana was often presented as a sexually available woman, and her body was

\footnotetext{
${ }^{35}$ Anon., 'La faccia nera del festival', Sorrisi e Canzoni TV, 14 January 1968, pp. 18-19.

${ }^{36}$ E. Baldi et al., 'Rosso e nero', Sorrisi e Canzoni T, 11 February 1968, p. 21.

${ }^{37}$ L. Saint Paul, 'A casa di Armstrong un incontro indimenticabile', Sorrisi e Canzoni TV, 29 December 1968, pp. 22-25.

${ }^{38}$ See, for example, the opening credits of the film Stasera mi butto, dir. by Ettore Fizzarotti (Titanus, 1967).

${ }^{39}$ Sabato Sera (RAI, 1967; RAI Teche Archives).
} 
objectified. For example, in the film Stasera mi butto Falana's body is constantly under the scrutiny of both women and men: when she walks on the beach boardwalk, the camera lingers on the men's desirous gaze and the women's envying gaze. The focus on the dancer's body is also highlighted by the fact that in the film Falana speaks mostly in English, and the film does not offer any subtitles of her lines - underlining the rather inconsequential role her personality plays in contributing to the storyline. The different portrayal of the two television personalities might suggest that Falana's objectification was not only due to her skin colour but also to her nationality, as American women were perceived to be more sexually emancipated than Italian women.

Lara's wedding in 1968 and the birth of her daughter Manuela in 1969 significantly contributed to her Italianisation. By becoming Pier Quinto Cariaggi's wife, Lara conformed to the traditional role of the Italian woman as wife and mother, in this way becoming increasingly respectable to an audience of Italian families. In an interview to Sorrisi e Canzoni TV, Lara claims that her marriage is not based on economic interests. ${ }^{40}$ The pictures accompanying the article feature Lara in the family context, thus deprived of all the elements of glamour that characterised her television performances. The significance of Lara's role as wife and mother in her star construction also influenced her subsequent television appearances. At Canzonissima 1970, Lara tells presenter Corrado (Corrado Mantoni) that she has become a mother, and she addresses her daughter, asking her to go to bed after her performance. The following year, at Canzonissima 1971, Corrado also asks her why she chose 'Saint Paul' as a surname and she replies 'Veramente per gli amici penso che basti votare per Lara', therefore emphasising her Italian name over her foreign surname.

\footnotetext{
${ }^{40}$ G. Vesigna, 'I segreti di Lara', Sorrisi e Canzoni TV, 1 June 1969, pp. 22-24. Lara also appears in the magazine cover of this issue.
} 
If Giulia Guazzaloca is right to claim that Italian television in the 1960s functioned to create a common national identity, ${ }^{41}$ it could be argued that Lara's popularity as a national icon shows that Italianness in this period was not strictly defined along the dichotomy between whiteness and blackness, and it was constructed by including the many Italians with a brown or darker skin colour who did not fit the idea of hegemonic whiteness. Nonetheless, it is interesting to note a certain morbid curiosity to identify Lara's origins in several popular magazines. For instance, Giovani and Playboy define Lara as an Amharic princess, therefore increasing the mysteriousness of her African origins, ${ }^{42}$ while in 1973 the magazine Settimana Extra sends a reporter to Asmara in order to find Lara's 'real' mother. ${ }^{43}$ The attempt to trace Lara's origins shows an anxiety for her mimetic labour: to paraphrase Homi Bhabha's ideas about mimicry in a colonial and postcolonial context, she is Italian - therefore 'resembles' the majority of the 1960s RAI viewers - but she is also bears a bodily difference that 'menaces' the supposed racial homogeneity in Italian society. ${ }^{44}$

\section{Afro Style and Black Atlantic: Lara and Melissa (1967-1981)}

While television programmes aimed at a family audience tended to portray Lara as an Italian star, teen magazines and the cover of some of her albums emphasised her blackness and international allure, in order to align her music and star persona with several trends coming from overseas and arguably increase her commercial success and popularity with music aficionados. The cover album of Lara's first album, Lara Saint

\footnotetext{
${ }^{41} \mathrm{G}$. Guazzaloca, Una e divisibile: la Rai e i partiti negli anni del monopolio pubblico (Florence: Le Monnier, 2011), p. 137.

${ }^{42}$ Anon., 'Lara Saint Paul: mi va di gridare che sono felice!', Giovani, 4 March 1968, 78-79 (p. 78); and L. Saint Paul, ‘Tutti al sole con Lara! Saint! Paul!', Playboy, July 1978, p. 36.

${ }^{43}$ David, 'Lara: Ecco chi è la tua vera mamma!', Settimana extra: attualità, politica, cultura, 20 July 1973, pp. 6-8.

${ }^{44}$ Homi Bhabha, The Locations of Culture (London: Routledge, 1994) p. 88.
} 
Paul (1967), depicts the singer bleached blonde and wearing a leopard print fur. The album cover incorporates the image of two golden lions, thus associating Lara with an African imagery. In the back cover, a short text by Cariaggi identifies Lara as a meticcio singer and claims that she was born in Asmara to an Italian father and a Somali mother, therefore mis-situating her Eritrean origins. Interestingly, this description does not state that Lara is Italian, but rather says that she works in Italy because her family lives in this country and that is where she started her career. Moreover, the piece clearly connects Lara's singing style with foreign black singers such as Louis Armstrong and Lionel Hampton, as it features their endorsements of the singer. The cover states that not only does Lara sing in English - the album contains two songs in this language which were part of the original scores of two Italian films, Troppo Per Vivere Poco Per Morire, ${ }^{45}$ and Rapporto Fuller Base Stoccolma ${ }^{46}$ - but she can also sing in Spanish, French and German. This presentation shows an attempt to internationalise Lara's figure, by connecting her musical career with that of other black singers who gained international popularity, instead of emphasising her Italianness.

Lara's pictures on the album cover clearly evoke Etta James' style, since the latter was also known for her 'impish smile, blonde hair, and dark eyebrows'. ${ }^{47} \mathrm{~A}$ superficial reading of Lara's straight blonde hair might indicate Lara's conformity to white standards of beauty. This new hairstyle can also be read in opposition to Tanya's hair, which was left at a 'natural' state. However, if we consider hair as shaped by culturally determined creative and re-creative acts, the difference between her former 'exotic' and late 1960s 'artificial' appearance might appear implausible. Indeed,

\footnotetext{
${ }^{45}$ Troppo per vivere poco per morire, dir. by Michele Lupo (Fida Cinematografica, 1967).

${ }^{46}$ Rapporto Fuller base Stoccolma, dir. by Sergio Grieco (Fida Cinematografica, 1968).

${ }^{47}$ M. Mahon, 'African American Women and the Dynamics of Gender, Race, and Genre in Rock 'n'Roll', in Issues in African American Music: Power, Gender, Race, Representation, ed. by Portia K. Maultsby and Mellonee V. Burnim (New York; London: Routledge 2017), p. 292.
} 
Kobena Mercer argues against this distinction, claiming that the choice of an hairstyle by African American women carries political implications:

when hairstyling is critically evaluated as an aesthetic practice inscribed in everyday life, all black hairstyles are political in that they each articulate responses to the panoply of historical forces which have invested this element of the ethnic signifier with both symbolic meaning and significance. ${ }^{48}$

To use Shirley Anne Tate's words, Lara's straight blonde hair seems to 'speak of whiteness incorporated into Black style' and 'highlight[s] the singer's Blackness through its very fakeness'. ${ }^{49}$ On this cover, Lara seems to identify not with whiteness and Italianness, but rather with the stylization of blackness that was employed by coeval African American singers. Tanya's and Lara's hairstyles were both artificially produced, but while the former referred to the colonial idea of Africa as the state of nature, the latter saw as aesthetic model the idea of blackness that was constructed within the Black Atlantic diaspora as a whole.

The media representation of Lara's star persona or her skin colour was not only directly associated with trends coming from the United States, but it can also be connected with the Italian reception of the Afro trend, a style that had developed since the mid-1960s as part of the Civil Rights Movements' struggles for the recognition of equal rights for black people in the United States. Through the slogan 'Black is Beautiful', this movement also advocated for a reconsideration of the standards of black beauty, which up to that point were strongly influenced by white beauty standards. ${ }^{50}$ The Afro hairstyle in particular became a 'declaration of [African Americans'] racial

\footnotetext{
${ }^{48} \mathrm{~K}$. Mercer, Welcome to the Jungle: New Positions in Black Cultural Studies (London: Routledge 1994), p. 104.

${ }^{49}$ Tate, Black Beauty, p. 50.

${ }^{50}$ S. B. Kaiser, Fashion and Cultural Studies (London; New York: Bloomsbury, 2012), p. 80.
} 
pride'51 and a political statement, as it aesthetically expressed a direct involvement or an indirect support to the Civil Rights Movement. However, the Afro hairstyle and fashion - the appropriation of 'ethnic' elements such as necklaces, earrings, bracelets and African prints -, soon became a global commercial trend, reaching Italy in the late 1960s. Lara was one of the first Italian artists to employ elements coming from African American culture in her style. The Afro trend, however, was not only reserved to black Italian stars: other artists, such as composer Lucio Battisti - who started his career as a singer in 1968 by adopting a hippy fashion and an Afro hairstyle - or Marcella Bella who wore a thick Afro in 1972 - testify to the success of this style and the appropriation of African American aesthetics in Italy and elsewhere. ${ }^{52}$ It is interesting to note that teen magazines saw Lara's use of this style as an adornment of her body and a privilege acquired thanks to her marriage and her position of power in the music and television industries:

Adesso che ha raggiunto il successo, che è la signora Cariaggi [...] certe volte è lei stessa a permettersi degli 'esotismi'. Come per esempio sottolineare ancor più il suo tipo con abiti di ispirazione africana e con trucco che mette in rilievo i suoi lineamenti marcati. ${ }^{53}$

The article explains how, by marrying a wealthy Italian man and being a star, not only has Lara become more Italian, but she can also choose whether to 'become' exotic or black, by adopting style features recalling African garments or by wearing heavy makeup. Class upward mobility, in other words, allows Lara to use darkness as an adornment

\footnotetext{
${ }^{51}$ A. D. Byrd and L. L. Tharps, Hair Story: Untangling the Roots of Black Hair in America, 2nd edn (New York: St. Martin's Griffin, 2014), p. 54.

${ }^{52}$ For example, white British singer Julie Driscoll also adopted a Afro hairstyle in the late 1960s.

${ }^{53}$ Lamberti, 'Il tema di Lara’, pp. 35-36.
} 
of her body, which in this case is not seen as a sign of inferiority, but rather as a stylish and fashionable choice.

The arrival of the Afro trend in Italy at the end of 1968 affected not only fashions and hairstyles, but also music trends and media stars. In April 1968, an article published in the teen magazine Ciao Big claimed that in Italy 'è il momento delle mulatte', ${ }^{54}$ as from the spring of 1968 Italian female singers of African origins began to be present in the national popular music scene. For instance, Maria Rosa Chimenti was the daughter of an Italian father and an Eritrean mother, and she started her career as a singer in 1968 with the stage name Melissa. The media construction of Melissa's star persona shows how the attitude towards race appears to change suddenly at the end of the 1960s. In an article published in April 1968, Melissa is presented as an 'Italianised' star. The journalist explains that 'è stata complicata [...] la preparazione del “personaggio” da proporre all'attenzione del pubblico’ because in order to be accepted by the Italian audience, several changes were imposed upon the singer, such as straightening her hair, abandoning excessive make-up and learning how to move 'come una donna di classe, facendole fare lunghe passeggiate con un libro sulla testa, alla maniera delle indossatrici dei grandi ateliers'. ${ }^{55}$ The article is accompanied by a 'before/after' series of pictures, in which we see the 'old' Maria Grazia Chimenti in black and white, with curly hair and a heavy kohl make-up, compared with the 'new' Melissa, who appears in a colour photograph with straightened hair and a fashionable outfit on. Conversely, in an article which appeared in Giovani just a few months later, in November 1968, Melissa's ethnic features - her African origins, her brown skin, her being a mixed-race person - are celebrated as constitutive parts of her success. As soon

\footnotetext{
${ }^{54}$ M.A., 'Vuole il giardino per un ghepardo', Ciao Big, 5 April 1968, 4-5 (p. 5).

${ }^{55}$ Ibid.
} 
as the Afro style became more widespread in Italian culture, mulatto Italian singers could perform their 'Africanness':

Melissa sorride, mettendo in mostra una fila di denti bianchissimi, che fanno contrasto con la sua pelle color caffelatte. [...] Melissa è una bella ragazza mulatta: sua madre è africana, suo padre italiano. È nata in Eritrea, diciannove anni fa, poi è venuta a stabilirsi a Roma con la sua famiglia. [...] E ha anche un grosso desiderio: quello di riuscire a 'battere' la sua 'rivale' mulatta, Lara Saint Paul. ${ }^{56}$

The article shows that the commercial circulation of the Afro style made possible the acceptance of the ethnic 'other' in Italian popular culture, even for mixed-race artists who were not married to a powerful man like Cariaggi.

Arguably, there is a difference in the presentation of Melissa and Lara: while the former singer's star persona was constructed by drawing on a colonial imagery, the latter had a more explicit reference to African American culture. Album covers show the influence of different cultural references which helped to construct their star personas. For instance, Melissa's first album La spiaggia è vuota (1968) portray her as an African singer, with 'ethnic' earrings, and curly black hair. The back cover of this album also describes her with strong colonial overtones:

MELISSA è una bella ragazza mulatta, nata ad Asmara 20 anni fa [...] questa ragazza spontanea, piena di talento e di vitalità ha veramente qualcosa di 'diverso' dalle sue coetanee. Ogni atteggiamento di MELISSA è un misto di grazie infantile e maturità. La sua indole è in realtà volitiva, indipendente e irruente, ma il suo sguardo è dolce.

It is only in the 1972 album Apparizione that Melissa appears with a bouffant, like other coeval African American artists, therefore conforming to a new model of blackness,

${ }^{56}$ Anon., 'Melissa vuol diventare più famosa di Lara St. Paul', Giovani, 21 November 1968, 4849 (p. 49). 
which was more appealing for the early 1970s audiences. Melissa's physical changes can be interpreted as an adaptation to a more successful model of blackness inspired by African American culture, which Lara had embodied since the beginning of her career with this stage name. In other terms, it might be argued that Melissa had less success than Lara precisely because her star persona referred to an old-fashioned and colonial model of black beauty.

The adoption of the Afro trend by meticcio singers such as Lara and Melissa, however, cannot be reduced to a matter of fashion. The wearing of a style with political and anti-racist meanings also had a subversive potential, which sometimes appears in media discourses about Lara in the late 1960s. The 'ethnic' presentation of an Italian artist of African origins between the end of the 1960s and the beginning of the 1970s might signal an increasing awareness about racial discrimination. While in March 1968 the magazine Giovani calls Lara 'la cantante-color-cioccolata-al-latte' and 'il "cioccolatino" della canzone italiana', ${ }^{57}$ descriptions of Lara that indulged on skin color started to be perceived as problematic in 1969:

Il colore della pelle è stato sempre per Lara Saint Paul una particolarità ed un handicap. Ancora oggi difficilmente un presentatore le risparmia allusioni benevole come 'saporito cioccolatino', 'profumato chicco di caffè', 'faccetta nera' ed altre amenità del genere. Un mini-razzismo, scherzoso e cordiale, che comincia però a stancarla. Teme infatti che il pubblico si soffermi troppo sul suo aspetto fisico, tralasciando di considerare le sue doti di cantante. ${ }^{58}$

This article refers to the presence of a playful racism, and it therefore signals that racist interpellations were still accepted in 1960s Italian society. However, Lara does not find this racism cheerful, but rather annoying. By asking her audience to appreciate her

\footnotetext{
57 'Lara Saint Paul: mi va di gridare che sono felice!', p. 79.

${ }^{58}$ Lamberti, 'Il tema di Lara’, p. 35.
} 
singing skills over her physical appearance, Lara uses her position of power in the music industry to challenge offensive definitions of identity based on the colour of her skin.

Lara's affiliation with 'a transnational structure of feeling which links diverse populations in a network of Black beauty ideology and practices'59 through her Afro seems even more evident in the early 1970s, when the Afro style became even more widespread thanks to funk and disco music. The 1973 LP album Lara Saint Paul is heavily influenced by African American culture and the funk music style, and Lara's large Afro wig takes up sizable space in the composition of the album cover. The cover of the 1972 seven-inch album that precedes it, Se non fosse tra queste mie braccia lo inventerei - a song presented at Sanremo in the same year - features Lara with a thick afro hairstyle, and wearing a red dashiki. However, this presentation does not correspond to Lara's looks at Sanremo 1972 and 1973, where her hairstyle is a long choppy bob. As the previous section has highlighted, television representations of the singer functioned to Italianise and whiten her, even in the 1970s.

Lara's style in the late 1970s continued to be inspired by African American coeval models, but she was more often represented as a sexually alluring woman. In particular, the years from 1977 to 1979 represent an exotic-erotic turn in Lara's career, after four years of no significant public appearance. Her 1977 experimental funk album Saffo Music presents her head only among tropical fruits, thus objectifying this part of her body. However, she is not depicted as a passive presence, but rather as a seducer. Lara winks at the audience, and she is smiling. A plastic banana almost touches her cheek, thus adding a sexual and comic connotation to the scene. The reference to Sappho, and therefore to lesbianism, in the album title might evoke the male

\footnotetext{
${ }^{59}$ Tate, Black Beauty, p. 1.
} 
heterosexual erotic fantasy of participating or observing two women involved in sexual acts. The single released from this album, I feel so nice (1979), presents red lips on a black cover, further alluding to sex and blackness. As Maureen Mahon argues in her analysis of sexualised black female images in the 1970s, the exposed sexuality of Lara in this period can be seen as a 'double-edged sword' rather than a mere adherence to patriarchal norms:

It can be read as a kind of empowering move in which the woman is in control of her body and her desires; at the same time, however, women presenting themselves as sexual agents are often mistaken for sexual objects. Furthermore, with sexuality in the foreground, other aspects, importantly the artist's talent, can be easily overshadowed. ${ }^{60}$

In other words, Mahon seems to suggest that the sexualised representation and selfrepresentation of black stars in the 1970s cannot straightforwardly be seen as an objectification of women's body, but it might as well represent a self-aware attempt to portray an ironic non-white model of beauty. In light of this analysis, Lara's smiling face on the cover of Saffo Music presents an ambiguous image of sexualised black beauty.

Lara's sexualization cannot be dissociated from coeval representations of African American singers, who in this period started also to be highly sexualised. In particular, the representations of African American singer Tina Turner as a wild and sexualised black woman might have influenced Lara's construction of blackness. According to bell hooks, the construction of Turner's star persona as a 'wild sexual savage' in this period 'was perfectly compatible with prevailing representations of black

\footnotetext{
${ }^{60}$ M. Mahon, 'African American Women and the Dynamics of Gender, Race, and Genre in Rock 'n’Roll', p. 301.
} 
female sexuality in a white supremacist society'. ${ }^{61}$ Hooks' comment might be better understood by looking at the cover of the funk album Tina Turns the Country On (1974), which represents Tina Turner scantily dressed and exposing her cleavage. A quick look at other funk cover albums of the 1970s - such as Betty Davis' They Say I am Different (1974), Diana Ross’ Baby, It’s Me (1976), Millie Jackson’s Feelin’ Bitchy (1977), Chaka Khan's Chaka (1978), and Parlet's Pleasure Principle (1978) - show how references to a wild sexuality characterised representations of female black singers in the 1970s. Therefore, it seems that Lara's representation replicated the themes, motifs and symbols associated with her music style in this period.

The presentation of Lara in the late 1970s combined the dominant references to sexualised African American women with allusions to a colonial imagery, after a decade of detachment from references to colonialism in her presentation. This return perhaps functioned to adapt a new idea of blackness to a more familiar setting for the Italian audience, and testifies to the selective memory of colonialism that characterises the cyclical resurgence of colonial elements in Italian culture and society. ${ }^{62}$ For instance, Lara posed naked for the magazines Playboy, Playman and Ciné Revue Photos, ${ }^{63}$ therefore contradicting her 1968 interview in which she left no room for this possibility because she was Italian. Her presentation in Playman clearly references colonial descriptions:

L'istinto quasi primordiale dell'Africa, e quello raffinato dell'Europa. [...] un fiume di erotismo puro in cui si specchiano le nostre timide nostalgie e i nostri più

\footnotetext{
${ }^{61}$ b. hooks, Black Looks: Race and Representation (Boston, MA: South End Press, 1992), p. 67.

${ }^{62}$ G. Proglio, 'L’Italia e il passato coloniale. Riflessioni e considerazioni a margine del dibattito storiografico’, Memoria e ricerca 1 (2018), pp. 113-32.

63 'Tutti al sole con Lara! Saint! Paul!’, pp. 36-43; Anon., 'Lara Saint Paul: Disco Music e un tocco di classe', Playman, 5 May 1979, pp. 54-60; and Anon., 'Lara Saint Paul', Ciné Revue Photos, December 1979, pp. 42-47.
} 
sfrenati desideri, la nostra impotenza (relativa, per fortuna, relativa...) di maschi di fronte al miracolo di una pura, essenziale, autentica, tesa, scoperta femminilità. ${ }^{64}$

This passage indulges on the trope of Africa as a place that can awaken the male primordial instincts, perhaps insinuating that the modern lifestyle and the conquests of women's rights have inhibited them. In Playmen, Lara is animalised: she wears a leopard skin and she poses next to a ceramic puma. The representation of Lara in this period stands in stark contrast with the rest of her career, where she is a model of elegance. At the end of the 1970s, and in a different media product - namely adult magazines - she endorses the global image of the highly sexualised black woman, and references to her being Italian disappear.

It should be noted that in this period black television and cinema stars like Zeudi Araya and Ines Pellegrini - who appeared naked on the front cover of Playboy in 1974 - gained success as erotic-exotic icons in Italy, clearly drawing on colonial fantasies. ${ }^{65}$ Melissa also became an actress in several erotic movies, including Papaya dei Caraibi. $^{66}$ The objectification of black women's bodies was pervasive in the Western society of the 1970s, but Lara's case - which should not be considered by looking exclusively at her representation in pornographic magazines - seems to show that the African American representation of blackness moulded and influenced the construction of her black female body more than the European colonial imaginary, which is the main inspiration for the construction of stars like Araya or Pellegrini. ${ }^{67}$ Although some of Lara's media descriptions in this period evoked colonial tropes, she did not fit the

\footnotetext{
64 'Lara Saint Paul: Disco Music e un tocco di classe', p. 55.

${ }^{65}$ R. Giuliani Caponetto, 'Zeudi Araya, Ines Pellegrini e il cinema italiano di seduzione coloniale', in L'Africa in Italia, ed. by L. De Franceschi, pp. 109-24.

${ }^{66}$ Papaya dei Caraibi, dir. by Joe D’Amato (Mercury Cinematografica, 1978).

${ }^{67}$ On this topic see, G. Giuliani, 'La razza fuoristrada. Veneri nere tra memoria coloniale e orizzonti globali', in A fior di pelle. Bianchezza, nerezza, visualità, ed. by E. Bordin and S. Bosco (Verona: Ombre corte, 2017), pp. 235-50.
} 
colonial stereotype of the bella abissina or the 'beautiful, docile, but mostly sexually available' woman from Abyssinia. ${ }^{68}$ Unlike Zeudi Araya, Lara was more often represented as lustful and provocative, an image which is unlikely to be found in Italian colonial literature and show the influence of US culture in the construction of Lara Saint Paul in the 1970s.

\section{An Intemational White Star: Lara (1981-2018)}

In the last part of her career, Lara has been mostly presented as an international white singer. Throughout the 1970s, she became an ambassador of Italian and American music abroad. For instance, in 1972 and 1977 she released two albums in Bulgaria therefore representing Western music to the Eastern Block market - where she performed in English, and she toured in Japan and South America in 1978. Her popularity increased in the 1980 s thanks to disco music and music production. ${ }^{69}$ The cover of her disco dance album Bravo (1981) features Lara with her hair down and her skin is much whiter than it was presented on album covers during the 1960s and 1970s. Lara wears a white dress, which can be seen as a further extension of the mimetic qualities of her body towards whiteness. By the songs she sings, it is not possible to identify her either as an Italian or an American star, as Bravo and Bravo 2 (1982) contain songs in English and disco rearrangements of popular Italian songs translated in English such as Gabriella Ferri’s ‘Sempre’, the opera aria 'Va, pensiero’ from Giuseppe Verdi’s Aida (1871), and 'Romagna mia', a popular Italian waltz written in 1954 by Secondo Casadei. The tension between Lara's international and national identity is

\footnotetext{
${ }^{68}$ S. Ponzanesi, Paradoxes of Postcolonial Culture. Contemporary Women Writers of the Indian and Afro-Italian Diaspora (Albany, NY: SUNY Press, 2004).

${ }^{69}$ Lara was a producer and host for the 1988 Sanremo Music Festival at the Casino di Sanremo, and she also produced a documentary on the Italian tenor Luciano Pavarotti, The Best Is Yet to Come (1995).
} 
evident in her appearance in the 1981 TV show Discoring. ${ }^{70}$ The singer has straight hair to her shoulders and she is dressed like a cowgirl. When asked by the interviewer about her new album, she says that with this album she wanted to revisit 'la nostra musica popolare'. This claim is confusing, since Lara sings the first song from Bravo, called 'California USA'. To put it in blunt terms, it seems that Lara's celebrity gives her a transnational white status, which goes far beyond Italian popular culture.

Moreover, Lara continued to translate and import American music, culture and trends to Italy. She brought aerobic dance to Italy in 1983, working closely with Jane Fonda. The cover of the album Aerobic Dance portrays the singer while she is dancing and wearing a fitted leotard. Lara also worked with other white American or international stars such as Frank Sinatra, Liza Minelli, Luciano Pavarotti and Harry Belafonte. For instance, these stars performed in Lara Superspecial (1992), Lara's last live show which celebrated her successful career. Moreover, Lara hosted the 1989 television recording of the Italian concert of Frank Sinatra, Liza Minelli and Sammy Davis, entitled Arrivano Frank, Liza and Sammy. ${ }^{71}$ If one should note that Lara mentions her 1968 performance with Louis Armstrong in most TV shows in which she participates as a guest, it is also true that she seems to increasingly associate herself to a white US culture and music in the last part of her career. A reason to explain this fact might be that starting in the 1980s, immigration from Africa became increasingly visible in Italian society, therefore defining Lara as meticcia or black would have associated her persona with a group of people to whom she was not perceived as

\footnotetext{
${ }^{70}$ Discoring (RAI; 1980-1981; RAI Teche Archives).

${ }^{71}$ Arrivano Frank, Liza and Sammy (RAI, 1989; RAI Teche Archives).
} 
belonging to in terms of class and status. Moreover, the 1980s saw a 'white backlash' in the US and in the UK, which deeply influenced Italian popular culture. ${ }^{72}$

In the early 2000s, Lara performed several songs from Frank Sinatra's repertoire and talked about their friendship in the television programmes Io tra di $\operatorname{voi}^{73}$ and Unomattina. ${ }^{74}$ These two appearances were Lara's last singing performances on television, and further connected the singer's persona with an international white star system. After these performances, her television appearances deviated greatly from her past glamour, and showed a very vulnerable person, who had seemingly not gained lasting benefits from her celebrity. Lara and her daughter Manuela were invited to some television programmes to discuss the increasingly difficult economic and health situation of the singer. ${ }^{75}$ Due to her economic struggles, in 2014 she bestowed a life annuity from the Italian government thanks to the law 8 August 1985, n. 440, which grants a monetary contribution to prominent Italian citizens who excelled in their field. Arguably, the official recognition of her artistic contribution to Italian culture came at a time in which Lara Saint Paul was long forgotten by many Italians. Silvana Areggasc Savorelli died on 8 May 2018, after a long illness caused by an intestinal cancer.

\section{How Race is Made in Italy: Silvana Areggasc Savorelli’s Transnational Identities}

As Fleetwood argues, the relation between how blackness is performed by individuals and how it is associated to a group is difficult to determine:

[Blackness] is not rooted in a history, person, or thing, although it has many histories and many associations with people and things. Blackness fills in space

\footnotetext{
${ }^{72}$ R. Hewitt, White Backlash and the Politics of Multiculturalism (Cambridge: Cambridge University Press, 2005), p. 18.

${ }^{73}$ Io tra di Voi (Mediaset, 2002).

${ }^{74}$ Unomattina (RAI, 2007).

${ }^{75}$ Including Domenica In (RAI, 2013) and TGcom 24 (Mediaset, 2017).
} 
between matter, between object and subject, between bodies, between looking and being looked upon. It fills in the void and is the void. Through its circulation, blackness attaches to bodies and narratives coded as such but it always exceeds these attachments. ${ }^{76}$

This assumption is particularly true in the case of Silvana Areggasc Savorelli, given that her successful career in Italian popular music and television enabled her to change the perception of her race and ethnicity, which is an opportunity that other people of African origins living in Italy might not have had. It should also be noticed that Savorelli's lighter skin tone provided her with mimetic qualities and certainly facilitated the transformations of her star persona. Savorelli's multifaceted meticcio stardom and her negotiation of difference that at times seemed relatively free of racial bias is rather exceptional in contemporary Italian history and popular culture. Savorelli's multiple transnational belongings - expressed through the mastery of several musical idioms and fashion styles - stakes a claim for racial variety in the national narrative, and it can be seen as a contestation of Italy's supposedly homogeneous white society. Italian popular media products such as family-oriented TV programmes constructed Lara's persona as 'Italian', therefore envisioning a flexible national identity which could also include meticci Italians. Album covers and teen magazine articles show the increasing significance of foreign trends in contaminating and influencing the popular media construction of a modern Italian identity.

Savorelli's presence as a protagonist of Italian television and popular music in the 1960s can be seen as an accomplishment in the face of racist disenfranchisement and within an almost exclusively white arena. Her physical transformations escape phenotypical determinations and show the constructedness of race for a meticcio star in Italy by resignifying the meaning of blackness and whiteness, as well as the meanings

\footnotetext{
${ }^{76}$ Fleetwood, Troubling Vision, pp. 5-6.
} 
of Italianness and foreignness. Lara's multiple renegotiations of these concepts present meticcio skin as a mobile and translatable concept, which escapes and is in close dialogue with hegemonic ideas of blackness and whiteness. By affirming this, this article does not want to question the fact that visual culture is a space for regulation of bodies and that 'the commodification of Otherness' is present within the market of ethnicity and style, ${ }^{77}$ but it aims at pointing out that Savorelli's body is neither docile nor agency-less thanks to her celebrity and class position.

A close look at Savorelli's career also moves from the idea of racial identity to a gradual synthesis of different cultures. The analysis of Savorelli's popular media representations shows that although the Italian colonial experience has had a pivotal role in constructing ideas of the black 'other' in Italian society, other transnational experiences have certainly shaped the perception of race in more recent times, and especially from the post-war period onwards. For instance, the influence of African American popular culture and the ideals expressed by movements for the emancipation of African Americans on Italian society appear in the media construction of Savorelli's star persona. Similarly, the fact that Lara tended to be associated with a predominantly white international popular culture at the end of her career could indicate that African American culture has had a lesser influence on popular stars in Italy than in the 1960s and 1970s.

In conclusion, throughout her career Savorelli showed multiple ways of reconfiguring her belonging in terms of nationality and race. Although the rejection of white-oriented beauty standards was not constant throughout her artistic career, her performances of whiteness and blackness contributed to break the boundary between non-whiteness and Italianness. Her appearance shows a change in the media

\footnotetext{
${ }^{77}$ b. hooks, Black Looks, p. 21.
} 
construction of black Italianness, namely a discontinuity both with the colonial ideals and white normativity, and the significance of US culture in redefining black (and white) beauty standards in Italy. Savorelli tapped into the zeitgeist of racial, gender, and sexual liberation, exercising a creative way to negotiate, inhabit, work on, translate and performatively produce an Italian non-white body in Italian popular culture. Her body translated the varieties of forms of beauty that exist in the Black Atlantic diaspora, showing that the meaning of her skin colour is shaped according to the ideas and values that are associated with black people in different time periods of recent Italian history, including colonised people, civil rights activists, and immigrants. 